\title{
On Justice and Liberty in Natalia GinzburG'S NON-FiCTIONAL WRITINGS
}

\section{JOSEPH FRANCESE}

Summary: Natalia Ginzburg's value system impacted her poetics and her artistic production over her entire career as a writer. After the publication of Lessico famigliare (1963) through her death (1991) her youthful belief in the ideals of justice and liberty evolved to reflect the growing importance, for her, of social and economic equality: once liberty from fascist dictatorship had been achieved, justice became more prevalent in her thoughts and writings. Concomitant with the evolution of her belief system was an increasing pessimism concerning the development of Italian society, specifically the loss of what she called a "senso sociale": the ability and desire to put egoistic interests aside in the name of a greater good, engage one's fellow humans in a fecund, dialectical way, and transform reality. In her non-fictions of this later period, the focus of this essay, Ginzburg ponders the Italians' disengagement or retreat from the present, a situation that in turn was responsible for what she called our "broken relationship with the future" while advocating the interdependence of literature and world.

The present essay examines the evolution of Natalia Ginzburg's value system from the publication of Lessico famigliare (1963) through her death in 1991. Its goal is to enable us to better understand of how her belief system impacted her poetics. An understanding of Ginzburg's beliefs, as expressed in her non-fiction, will help the reader to establish links with her artistic production of this same period (although an analysis of her creative works is beyond the scope of the present study). Therefore, of particular interest will be the reconsideration of her youthful belief that justice and liberty, once wrested from Fascism, would provide some undefined sort of social panacea: over time, the importance of liberty will become more synonymous with the achievement of greater levels of social equality. After Lessico Ginzburg will demonstrate the ability to identify with the subjects of her narrations, so that she might better reflect transformations in Italian society. These transformations are amply documented and analyzed in essays written during the decade following the publication of Lessico. For this reason, these essays will be at the focus of our discussion.

The values discussed by Natalia Ginzburg (1916-1991) in Le piccole 
virtù (1962), a collection of non-fictional interventions, deal with the individual's function within the polis. In the 1940s and 1950s, liberty and justice, ideals learned at an early age in her parents' home, and later from the political organization in which her first husband Leone militated, Giustizia e libertà, were at the core of her belief system. As Natalia tells it, the importance of freedom in the immediate post-War period for many intellectuals of her generation, who had come of age under Fascism, was of a piece with a desire to unite their struggle for liberty with the fight of the less fortunate for economic justice.

However, without denying the impact of the war, even before the cessation of hostilities in Europe she contended that the acquisition of "big virtues" - such as generosity, courage, transparency and love of the truth, love for one's neighbor and self-denial, the desire to be and know (OP I, $883)^{1}$ - was contingent on the ability to identity with the oppressed and the marginalized:

si dirà che la beneficenza c'è e c'è stata sempre. Signore oziose che s'interessavano ai poveri ce n'è sempre state: collette ed istituzioni organizzate a scopo benefico ce n'è sempre state. Ma questa amabile e spesso generica attività non mi sembra abbia portato a risultati effettivi. Ciò che manca a noi tutti è il senso sociale, cioè una vera compartecipazione alla vita del prossimo: questo noi dobbiamo raggiungere e questo va insegnato ai nostri figli. (Ginzburg "I nostri figli," 227)

By "senso sociale" she meant leaving behind aspirations for one's own offspring and attempting to "amare nei nostri figli non soltanto il loro singolo essere nato da noi, ma l'intera società umana" (Ginzburg "I nostri figli," 227). This meant, at the very least, the extension of basic human rights and freedoms to all and continuous elevation of the social minimum (see, for example, OP I, 794).

With the onset of the Cold War, as tensions between East and West heightened, her desire to achieve justice and liberty did not remain static. At first she believed that freedom would have provided some sort of societal panacea (Ginzburg É difficile parlare di sé, 58). However her thoughts on the matter evolved, and, even though she feared the arrival, from Eastern Europe, of a new totalitarianism, she began to re-dimension the relative importance of these two ideals. As a result, over time Ginzburg

${ }^{1}$ All references, such as this one, to the 1986-1987 edition of Ginzburg's collected works, Opere raccolte e ordinate dall'Autore are indicated with the abbreviation $O P$ and volume number. 
came to understand that it was impossible to completely reconcile justice and freedom, and that neither of these two could be realized without the attainment of some form of social equality and economic equity. And since justice, more than freedom, was easier to square with equality before the law, the importance of justice came to be emphasized in her writings over the ideal of individual liberty. ${ }^{2}$

In essays Ginzburg wrote after the publication of Lessico famigliare freedom takes on a partially negative connotation, reflecting her rejection of its corollary, the repressive tolerance-to use Marcuse's term-that characterized the 1960s. The result of this shift in her thought was the repeated denunciation of the moral "tiepidezza" she believed had become the defining characteristic of Italian society. This belief, as we shall see, was at the root of her bleak view of Italian society, a defining trait of her fictional and non-fictional writings of the last two decades of her life. Thus, the focus of what follows will be the evolution of her value system, as evidenced in Ginzburg's non-fictional writings of the late 1960s (collected in 1970 in the volume Mai devi domandarmi) and early 1970s (collected in 1974 in Vita immaginaria) and the Scritti sparsi (from the mid- and late1970 s) brought together in her collected works. ${ }^{3}$ This topic is significant

2 In "Libertà," an essay to be discussed later, she writes: "[l]a parola "libertà» è cambiata in noi e forse nessuna parola ha subito una simile trasformazione. Forse la parola "luna» ha subìto una analoga trasformazione da quando la luna è stata esplorata. La parola "libertà» è comunque per noi oggi irriconoscibile se la mettiamo accanto a ciò che era. Invano cerchiamo nel nostro spirito l'antico squillo argentino e solenne. Esso si è spento da tempo. Noi da tempo abbiamo preso a pensare che la libertà sia forse una delle parole più oscure, difficili, complicate che esistano al mondo" (OP II, 624).

3 Mai devi domandarmi, Vita immaginaria, and her Scritti sparsi may now be found in volume 2 of the "Meridiano" dedicated to Ginzburg's ouevre, $O P$. The Scritti sparsi, essays written between 1975 and 1977, were chosen by the author for inclusion in her "Meridiano" from among "i vari articoli che ho pubblicato su giornali e non mai raccolti in volume." Their inclusion seems to indicate that the author intended them to give final punctuation to topics that may seem to have been left unresolved in previous writings. They are not in chronological order, as is the case with the other collections of non-fictions and the other subdivisions of the Meridiano. Instead, here there is a narrative hierarchy. To explain, "L'altro secolo," one of the last written but placed in the prominent lead position, evokes her childhood: as she explains in the brief introductory note, "Ho preferito seguire un ordine più intimo" (OP II, 1266). Its pendant, the concluding non-fictional piece, "Luna pallidassi," is a memoire of her adolescence as an aspiring writer who believed that "il far poesie era una cosa attaccaticcia e 
because, as already noted, these values informed her poetics, which, in turn, conditioned her artistic production.

Indeed, an important point of arrival of this evolution of her value system will be evinced in "Libertà," an essay now in Vita immaginaria, in which she argues that liberty must be, first and foremost, freedom "per un numero sterminato di persone libertà dalla servitù della miseria" (OP II, 626). From this, she derived the need to identify with the marginalized other and develop an abstract sense of justice. ${ }^{4}$ So, inherent in her repeated evocations of "il giusto e l'ingiusto," what is equitable and what is not, is the demand that the law should attenuate as much as possible the chance disparities created by birth; and the wish that merit should play a greater role than chance in determining one's destiny. ${ }^{5}$

From the mid-1960s through the end of her life Ginzburg's outlook became increasingly bleak: the world seemed evermore "uninhabitable," "dark," and "undecipherable" (qtd. Pflug Natalia Ginzburg, 126). Because much of the original impetus for such a view was rooted in the undoing of

contagiosa come la tosse" (OP II, 1325). Their epilogue is a very brief two-act play, "La poltrona" that deals with loose, when not completely unraveled relationships, suited to the fast and easy life-style of neo-hedonist non-commitment. Ginzburg's "Meridiano" was her literary legacy: the frontispiece indicates that this opera omnia was "collected and ordered by the Author." I Meridiani is a collection founded in 1969 by the Milanese publisher Arnoldo Mondadori with the intent of creating a prestigious and refined series of elegant volumes that included works of important Italian and world writers, spanning the literary spectrum from Ancient Greece through the Middle Ages and Renaissance, to the nineteenth, twentieth, and twenty first centuries.

${ }^{4}$ In her own words: "[s]embra infatti assai difficile stabilire quali delle umane richieste di libertà siano arbitrarie e quali siano sacrosante e legittime. Certo è che alcune richieste di libertà sono totalmente arbitrarie, essendo semplicemente la richiesta di conservare intatte private e personali condizioni di denaro o di fortuna a dispregio degli altri, ma esse usano nascondersi e coprirsi dietro richieste di libertà legittime e sacrosante e questo addensa sopra la parola «libertà» il buio e la confusione. [...] Forse sarebbe giusto e necessario che ognuno pensasse non alla sua libertà, ma a quella degli altri. Se ognuno pensasse a quella degli altri invece che alla sua propria, se fosse disposto a proteggere quella degli altri in luogo della sua, saremmo allora più vicini a una giusta divisione di beni, di privilegi e di libertà fra gli uomini” (OP II, 626).

5 See OP II, 589: "Quello che amavo, nel re, era proprio quello che da adulti ci induce a rifiutare la monarchia, e cioè il fatto che egli fosse stato scelto dal caso, senza nessun suo merito speciale." 
the traditional family unit, ${ }^{6}$ it must be stated straight away that her view of the traditional family in which she was raised was not uncritical:

Lo sfascio delle famiglie mi sembra una piaga del nostro tempo. Non che pensassi che le famiglie come erano prima andavano bene; penso che andavano malissimo. Però mi sembra che si sia creata un'abitudine allo sfascio, una sorta di contagio per cui tutte le famiglie si sfasciano e accettano di sfasciarsi. E a me questo mi sembra triste, mi sembra una piaga del nostro tempo. Mi sembra che una persona abbia bisogno di avere una famiglia--anche cattiva, repressiva, disastrata—alle sue spalle. E l'assenza di questo, mi sembra che faccia sí che le persone crescano con delle difficoltà. (Ginzburg É difficile parlare di sé, 183)

Rather, what is mourned here is, the "fixed identity" provided by the admittedly imperfect persons who surround the narrating voice of Lessico famigliare, especially her parents, those who provide the voice of that text with her moral compass (Woolf "Silent Witness," 257). Such fixed points of reference are of a piece with the silent guidance Ginzburg had argued, in Le piccole virtù that was also provided by the "mute presence of the dead" (OP I, 880).

For Ginzburg, contemplation of one's dead is a way of being-in-theworld: it guides our behavior when we live with an eye toward posterity, with the awareness that those who follow will look to our example for direction and will use as a criterion for judging us the state of the world we left behind.

In Le piccole virtiu Ginzburg had written of her realization that the attainment of adulthood is synonymous with the acquisition of the ability to contemplate "la presenza muta delle persone morte, a cui chiediamo un giudizio sul nostro comportamento attuale, a cui chiediamo perdono delle passate offese" (OP I, 880). In Mai devi domandarmi Ginzburg advances the hypothesis that "il fatto che si possa essere tanto felici ricordando persone che abbiamo perduto, che sono morte o che sono sparite dalla nostra vita avendoci tradito e abbandonato per sempre" (OP II, 168) is proof of the existence of God (OP II, 166-67).

Mai devi domandarmi has a metaphysical quality, or, better, demonstrates a worldly sacrality whose God prefers the believer who privileges "il benessere di un altro al suo proprio" (OP II, 170). In "Sul credere e non credere in Dio" (OP II, 164-76) Ginzburg argues that God's existence is

6 On this, see Baldini, "Questo mondo," 135; Boyers, "An Introduction," 23-24; and Gordon, "Surviving History," 45. 
evident in our need to ask fundamental questions about our existence, and that such interrogating defines our humanity. Moreover, by fulfilling the moral obligation to "individuare il proprio compito e di cercare di fare meglio che può quello che gli è chiesto" (Baldini "Questo mondo non mi piace," 132) our lives take on a religious dimension-that is not confessional, but ethical, because when we struggle against mortality we seek out a future in death. That is to say, in so doing we attempt to constitute ourselves a "mute presence" that will guide the moral behavior, in our absence, of our progeny-we live our commitment to to the world around us and to posterity. This worldly sacrality, grounded in the Golden Rule, animates her social engagement.

To explain, Ginzburg's father, an important "mute presence" for her even after his death in 1964, provided a model for choosing the primary readers of her writings, all metaphorical father figures. ${ }^{7}$ She counted on these first critics or preferred interlocutors to furnish her, as her father had done in other areas of her life, with "un giudizio chiaro, incrollabile, inesorabile e puro": 8

andiamo cercando in mezzo a noi quello di cui abbiamo una sete profon$\mathrm{da}$, un'intelligenza inesorabile, chiara e altera, che ci esamini con distanza e distacco, che ci osservi dall'alto d'una finestra, che non scenda a mescolarsi con noi nella polvere dei nostri cortili; un'intelligenza che pensi a noi e non a se stessa, misurata, implacabile e limpida nei confronti delle nostre opere, limpida nel conoscerci e rivelarci quello che siamo, inesorabile nel trovare e definire i nostri vizi ed errori. (OP II, 78)

Such protagonism had been supplanted by the "tiepidezza" mentioned above. The disappearance of strong points of reference, such as her father, had metaphorically rendered Italians "orphans" who begot "orphans" (OP II, 78). By the same token, the literary critic should not be worried at all

del nostro rancore; come non dovrebbe importare nulla del rancore dei figli a un padre sereno, che avesse una chiara coscienza di agire e pensa-

7 In this context see Ginzburg's "Interlocutori": "chi scrive, sente con forza la necessità di avere degli interlocutori. Di avere cioè al mondo tre o quattro persone, a cui sottoporre ciò che scrive e pensa e parlarne. Non gliene occorrono molte: bastano re o quattro. Il pubblico è, per chi scrive, una proliferazione e una proiezione di queste tre o quattro persone nell'ignoto e nell'infinito" (OP II, 177).

8 A similar authority figure from her youth was her middle school teacher: see "I baffi bianchi" (OP II, 146-59). 
re giustamente. Ma i critici sono oggi, come sono oggi i padri, fragili, nervosi e sensibili all'altrui rancore; temono di perdere degli amici, o di offendere dei conoscenti; $[\ldots]$ hanno paura di trovarsi soli a dire il vero in una società ostile. (OP II, 78)

Thus, in "mourning" the loss of fixed points of orientation, she lamented

la memoria della forza e della severità che proiettava, sulla nostra infanzia, la figura paterna. Soffriamo per l'assenza della critica, allo stesso modo come soffriamo per l'assenza, nella nostra vita adulta, d'un padre.

(OP II, 78)

This lost Father image had constituted "un saldo suolo per la ricerca e per l'affermazione del vero" (OP II, 80), and the basis for a more fecund dialectical rapport with the other. In her later years, she came to believe that such beneficial critical judgement had been replaced by a "tiepidezza" or, "una tolleranza che non è generata da pietà o comprensione, ma è fatta di ozio, di indifferenza e soprattutto di confusione" (OP II, 82). Thus, her pessimism, amply discussed in Mai devi domandarmi, was a result of the belief that "[l]a responsabilità individuale, e il giudizio morale, sembrano così destinati a scomparire dalla terra" (OP II, 185).

Because of this, the ability to dream, to imagine alternate ways of being — through "il solitario pensiero," accessed through creative activityhad been devalued (OP II, 110). Indeed, Ginzburg stresses in Mai devi domandarmi the importance of the ability to create an imaginary world and to situate oneself in the world of the other. The desire and capacity to imagine and identify with the other are at the core of both her creativity and her being-in-the-world. Paraphrasing what Blanchot said of Freud's discovery of transference, she first identifies with the other [l'autre] then she becomes another [autrui] $(1993,231)$. Or to phrase it differently, as Bauman, following Levinas has written, "[t]he self is born in the act of recognition of its being for the Other and thereby in the revaluation of the insufficiency of a mere Mitsein" ([to be with] 41).

In "Villaggi" Ginzburg writes of a childhood proclivity that lasted into adulthood and influenced her creative life: she would imagine herself living the lives of the residents of the hamlets she saw from the train and visited while on vacation (OP II, 119). In so doing she equates a certain kind of fantasy with reality. Because of this, she can admonish her reader to not "temere i romanzi, come qualcosa che possa portarci lontano dalla realtà" (OP II, 51-52). She wrote: 
i romanzi veri hanno il prodigio di restituirci l'amore alla vita e la sensazione concreta di quello che dalla vita vogliamo. I romanzi veri hanno il potere di spazzare via da noi la viltà, il torpore e la sottomissione alle idee collettive, ai contagi e agli incubi che respiriamo nell'aria. I romanzi veri hanno il potere di portarci di colpo nel cuore del vero. (OP II, 53)

Thus, a duty of the novelist is to enable to reader to think in a nonconforming way and to "raccogliere le tracce e per illuminar[e] le orme" of "il vero," verbal shorthand for traditional values such as sincerity, honor, and self-sacrifice and ideals such as justice and heroism, and the desire to distinguish between good and evil (Baldini "Questo mondo non mi piace," 131; OP II, 107). Novelists must know how to speak to their present, to the dynamic of human desire as it comes into conflict with material constraints; their work must be socially relevant. ${ }^{9}$ Novels are socially relevant when they enable their audience to liberate "la nostra persona reale" ( $O P$ II, 545), or to phrase it a bit differently, to overcome our egocentrisms:

La possibilità di inventare e costruire un mondo fantastico, di situarvi una vicenda e situarvi noi stessi e tutto quello che amiamo e detestiamo, era un tempo e ci sembra dovrebbe essere ancora una possibilità di vita libera e generosa. (OP II, 544)

However, the capability imparted by literature of conjuring "un mondo immaginario" (OP II, 52), of conceiving of worlds and lives other than our own, was no longer being transmitted to the younger generations. Instead, Italian society had been overtaken by a pervasive "immobilità" which, in her parlance, was synonymous with a refusal to emotionally identify with the other (Baldini "Questo mondo non mi piace," 131). And since novels, as she argues in Vita immaginaria, cannot be "inventati e costruiti con la fatica immobile di una mente addormentata," authors must avoid the "sortilegio maligno" of leaving behind "la nostra identità di individui" in a futile attempt at the sterile, positivistic analysis of a situation (OP II, 545). ${ }^{10}$

9 To use her own words, "Torniamo [...] a volte ai romanzi del passato, come a una miniera di beni fecondi e vitali che il nostro tempo ha perduto. Ma isolarli nel passato è come averli custoditi sotto vetro, come averli imprigionati nei musei della memoria. Abbiamo un estremo desiderio di romanzi nati dal presente, che portino i segni del presente, per mescolarli a quelli d'una volta e amarli insieme" (52).

10 Instead, she proposed, they should follow the example of a Moravia, who, at his best, uses his unusual powers of observation and description to create "una folla di gente che sembra lontanissima da lui" but that, in reality, he successfully identifies with because of "il suo sguardo amaro, penetrante e distratto" (OP II, 515). 
A cause and an effect of such "immobility," which she associated with the above-mentioned "tiepidezza," was the trend, in books written for children, toward "una letteratura anodina, che istupidisce, intorpidisce la fantasia" where instead "sentimenti [...] forti, non smorzati" were necessary:

Gli eroi della nostra infanzia erano perseguitati, calpestati, vittime di un destino feroce, di matrigne perverse. Erano però degli eroi. Oggi, nei libri destinati all'infanzia, non ci sono eroi. $\mathrm{Ci}$ sono i forti, i trionfatori, gli imbattibili, ma gli eroi, quelli che sopportavano le sventure versando pianti ma senza piegarsi, quelli non ci sono. (OP II, 86)

Literary heroes who triumphed over trials and tribulations had been emulated by the involved, interested citizens of her generation who had resisted fascism. Had such heroes not been displaced, they might have provided an alternative model to the "tiepidezza" that becomes the defining characteristic of a people, hampering the emotional growth of a generation of children: "[s]e non capiscono la tristezza, possono identificarsi con gli altri?" she asked; "possono sentire l'empatia?" (OP II, 87).

The generation following Ginzburg's had taken to concealing from their own children what literature was eminently qualified to reveal: qualities such as honesty, self-sacrifice, honor, and courage (OP II, 107). In so doing they had produced a new cohort overly attentive to "il rischio, il timore delle conseguenze," and bereft of fantasy, that is to say, a "creative life." As a result, Italy's young lacked the ability to look beyond their own selfinterest (OP II, 87). "Real" values had been forgotten; the ability to empathize with the less fortunate had been lost. This indifference for the fate of one's fellow human beings left a void that should have been filled with "wonder and passion" for all life (OP II, 41-42).

This belief is reiterated, in Vita immaginaria, in "Senza fate e senza maghi." Here Ginzburg objects to the proposal, advanced by a series of books for children,

che è bene demistificare agli occhi dei bambini l'idea del lupo. Però i lupi esistono. Si possono sfamare quanto si vuole, restano lupi e usano mangiare gli uomini. Oltre ai lupi, esistono persone che assomigliano ai lupi e il mondo ne è pieno. Non vedo quale vantaggio abbiano i bambini a non aver più paura dei lupi. È un errore credere che la paura sia un male. La paura, è necessario soffrirla e imparare a sopportarla. (OP II, 629)

Protecting children from harsh realities worked to their disadvantage: if they were to mature into adults capable of integrating themselves into a 
social consortium, they needed to learn to deal with the unpleasant aspects of life.

The "tiepidezza" or spiritual laziness under consideration is highly reminiscent of the "neo-hedonism" decried by Ginzburg's friend Pier Paolo Pasolini in his Scritti corsari. Ginzburg's convinction that the Italians had come to believe it "essential" that "tutto quello che facciamo e pensiamo è rivolto alla ricerca della felicità" (Baldini "Questo mondo non mi piace," 132) was partially behind her disagreement with feminism, especially as concerns the specific issue of abortion, a topic which we will consider further on.

As for the broader subject of feminism, Ginzburg's contention that all forms of identity politics, of which "woman's issues" constituted just one example, could not be separated from men's or, better, human issues, that is to say from her overrarching concern with social justice. This posture is articulated with great clarity in Vita immaginaria:

Penso che tutte le lotte sociali debbano essere combattute da uomini e donne insieme. Le rivoluzioni e le battaglie che hanno come fine il miglioramento della condizione umana, generalmente nascono da un'idea del mondo in cui uomini e donne sono mescolati. (OP II, 647)

In other words, the plight of women was not to be separated from that of men: "il punto di partenza non è la condizione delle donne, ma la condizione di tutti” (Baldini "Questo mondo non mi piace," 135):

Esistono stuoli di donne che vivono in stato di servitù. Battersi per la loro liberazione dovrebbe essere per tutti un problema essenziale. Esistono però altri stuoli di donne che non vivono in stato di servitù e appartengono alle socierà privilegiate. $\mathrm{Al}$ presente, esse non sono mai né adoperate, né umiliate. La loro vita è grondante di ogni specie di privilegio. (OP II, 648)

At stake was the proper balance of "justice and liberty":

le classi privilegiate essendo oggi quanto mai lontane dalla realtà, sovente danno origine a idee astratte e deformate, e il femminismo è una di esse. Perciò la protesta delle donne delle classi privilegiate contro la servitù che si nasconde nel loro destino non è per nulla una innocua protesta. Essa crea rumore e genera confusione. Essa distoglie l'attenzione universale dalla condizione dei veri diseredati e dei veri sfruttati. Distoglie l'attenzione dall'unica necessità esistente nel mondo attuale, che è distruggere gli attuali rapporti fra le persone e ricostruirli. (OP II, 650)

As Dombroski has explained, class-unlike social constructs such as race and gender-is not a natural but a "wholly social category." 
Integration of diversities — such as race, gender, ethnicity, and sexual preference-into the socio-economic mainstream does not undermine the dominant order, but instead reinforces it through the application of cosmetic reforms that do not put capitalism in jeopardy. Structural changes, however, unavoidably challenge the power of capital; emancipation "from economic necessity would amount to a change in the mode of production, which in turn would result in the alteration of the system's fundamental characteristics":

Social class then-despite the difficulties in determining what constitutes class affiliation in post-modern society-is intrinsically linked to the process of material production and constitutes the reality in which gender, race, and sexual preference are anchored. (Dombroski Marxism and Literature in the Postmodern Age, 7)

\section{For Ginzburg,}

poiché le conseguenze del disprezzo dell'uomo le soffrono in verità soltanto le donne che sono in stato di servitù, ciò significa che a essere adoperata e umiliata non è la condizione femminile, ma la condizione umana. Lo sdegno va rivolto non contro la specie virile ma contro chiunque offenda la condizione umana. (OP II, 649)

It should be noted that Ginzburg's argument against "separate social categories" extended to authors. She did not consider them blithe spirits, ${ }^{11}$ as Benedetto Croce, the person who dominated Italian intellectual life over the first half of the twentieth century, would have it. Rather, for Ginzburg "poetry" (we shall consider her specific use of this term further on) was synonymous with creating disquietude through verisimilar reflections of aspects of our shared human condition (OP II, 658). Therefore,

[f]also è pensare che la società deve lasciare libertà e privilegi ai poeti perché diano opere. Giusto è invece dire che una societa giusta dovrebbe consentire a ogni essere umano una medesima misura di liberta per esistere o con gli altri o solo. A tale misura di respiro e di libertà, ogni persona ha diritto senza scopo, senza ragione e senza spiegazioni. (OP II, 657)

11 See "La poesia:" “[I]a poesia si configura più giustamente come una particolare condizione dello spirito, non rara e non pregiata nel senso che può nascondersi nelle persone più insospettate, una condizione dello spirito dalla quale a volte nascono opere, a volte non nasce né nascerà mai nulla" (OP II, 656). Further on in this same essay she adds: "[f]also è [...] pensare la poesia come un capriccio di pochi, e falso è pensarla come un luogo di piacevolezza che i poeti apparecchiano per gli uomini" (OP II, 657). 
In sum, "[i]n quanto persone singole, i poeti hanno nei confronti del prossimo tutti i doveri e tutte le responabilità delle persone singole, non uno di più, non uno di meno" (OP II, 658).

Similary, Ginzburg's opposition to the creation of distinct social categories extended beyond women and writers to all marginalized groups. She returns to this topic in "Ragioni d'orgoglio," another of the "Scritti sparsi":

È sbagliato scoprire delle ragioni d'orgoglio, o delle ragioni d'avvilimento, nella propria nascita o origine, o nella propria condizione umana. Riguardo all'essere ebrei, è sbagliato esserne avviliti, è sbagliato gloriarsene. Riguardo all'essere omosessuali, è sbagliato esserne umiliati, sbagliato esserne orgogliosi. L'atteggiamento giusto è sentire, nei confronti della propria condizione umana, una totale indifferenza. Una fra le cose che oggi avvelenano il mondo, è la retorica sopra delle semplici condizioni umane. (OP II, 1304)

The perception of one's own solitude or diversity must be trumped by "il desiderio di rassomigliare ai nostri simili e il desiderio di condividere il più possibile il destino comune" (OP II, 1306) lest we risk losing sight of shared or "universal" values:

Sono di questa qualità e natura l'impegno civile, la solidarietà umana, il senso della giustizia, il coraggio. La parola "valori» è una parola che oggi adoperiamo e leggiamo con diffidenza, perché è stata adoperata troppo e male, si è scolorita e sembra non significare più nulla. Tuttavia è forse proprio questa parola che è necessario adoperare per mettere in chiaro ciò che può essere innalzato su un piano universale. Lorgoglio non è un valore e non ha qualità universale. (OP II, 1306-1307)

As for the more specific issue of abortion, in "Dell'aborto" (one of the Scritti sparsi) Ginzburg, while emphasizing the need to consider the ramifications of what she considered a very private decision on and within social context, cites the importance of class justice as the determining reason for the legalization:

E intollerabile che le donne povere rischino la morte o muoiano procurandosi aborti con i ferri da calza, e le donne ricche possano disporre di comode cliniche e non rischino nulla o assai poco. (OP II, 1300)

Ginzburg justifies this posture by citing the paramount need to protect the woman's privacy, while branding as "hateful" pro-choice arguments grounded in the right of the mother to do with her body as she pleases:

Trovo $[\ldots]$ odiose le parole "l'utero è mio e lo gestisco io»: in verità anche la vita è nostra, e nessuno di noi riesce a farne quello che gli pare. (OP II, 1299) 
Just as much of our lives is determined and conditioned by outside forces, we cannot ignore the consequences of our decisions on what surrounds us. This is especially true with the unique case of abortion, which she considers a form of killing. It cannot be justified by claiming that the mother be allowed to enjoy her own life unfettered; rather, the necessary legalization of abortion is not to be taken lightly; it is to be performed only when it could be considered the lesser of two evils:

Abortire vuol dire sopprimere non già una persona, ma il disegno remoto e pallido d'una persona; è chiaro che è un minor male che muoiono questi disegni remoti e pallidi, piuttosto che la madre che li porta dentro di sé; e ancora è un minor male che muoiano questi disegni remoti e pallidi, piuttosto che diventare essi dei bambini votati a un destino di fame. (OP II, 1300-1301)

Indeed, the very fact that abortion was considered a necessary, viable option for women, reflected what she called "our broken relationship with the future." This disconnect between present and future was at the root of the pessimism that characterized her later years.

To explain, Ginzburg contends it is impossibile to not favor the life of a mother over that of a virtuality, the fetus, which may be one of hunger and suffering (OP II, 1300-1301). However, she adds, if all hunger, suffering and sorrow were to be avoided, then, perhaps, it would be preferable to never give birth. Such a prospect, in turn, begs the question of why our relationship to the future seems to have become unbearably tenuous: we are no longer able to promise a future to our offspring (OP II, 1301).

It would seem that in indicating our inability to transmit the "promise of the future" to the younger generations Ginzburg is responding to the reshaping of the structures of experience consequent to relatively rapid sociological developments in Italy such as the massive internal migration subsequent to World War II and the so-called economic "boom" of the 1950s. These phenomena contributed to the dissolution of the traditional support system formerly provided by the nuclear and extended family and, consequently, to the shortening of commonsense perceptions of time: the weight of the past, and of traditions, in meaningful decision-making had been lessened. In turn, future horizons and expectations for long-term planning had been shortened. Therefore, she contended, abortion should be legalized, because it is a necessary means for expanding and enhancing class justice, not because it provides a "soluzione di comodo," a "neo-hedonistic" justification for the lost willingness to make personal sacrifices in name of a future good (OP II, 1301).

The world-view that comes forth through the non-fictional venues 
under analysis informs Ginzburg's poetics. For example, in "Mai devi domandarmi," the essay that gives its title to the eponymous volume, Ginzburg writes of how Wagner's Lohengrin allowed her to understand an important tenet of serious writing, that art must delude expectations. Life and art intertwine in the latter's reflection of "il vero": Lohengrin, which she saw as an adolescent allowed her to comprehend an important life lessonthat often, a small unhappiness (such as Lohengrin hiding his name from Elsa) can prevent a greater unhappiness - that impacted her art. She wrote:

capii a un tratto che, con un finale felice, quella storia crollava a terra, ne spariva ogni fuoco. Il segno della sua grandezza vampeggiava nell'errore e nell'irrevocabilità dell'errore. Era una verità elementare, ma ne rimasi trasecolata, e l'istante in cui ne presi coscienza è stampato nella mia memoria, avendo io allora per la prima volta nella mia vita intraveduto una superiorità della sventura sulla felicità. (OP II, 62)

Ginzburg believed that a desire for immediate gratification had caused a breakdown in the support structures traditionally available to the individual. She knew that the family in which she was raised was not without flaw; but she also knew that the shortcomings of her parents were not bred of egoistic, "tepid" indifference. As a result, "[l]e delusioni, [...] io credo che mi siano state salutarie perché imparare a sopportare le delusioni è quello che ci succede di dover fare nel corso dell'intiera esistenza" (OP II, 621). Indeed, because of her parents she had learned to understand and appreciate "il vero," which she also defined as the ability to "sentirsi felice di dare affetto senza ricevere nulla indietro" (OP II, 560).

In a different venue Ginzburg would argue that without the sort of "felicità di infantile e cieca innocenza" (OP II, 560) with which she was raised "è ugualmente assente il futuro" (OP II, 533). She had been protected by "la solidità e stabilità delle case e degli affetti, gli agi e gli ideali che che si alzavano intorno a loro" (OP II, 534). This is why "aveva un senso celebrare le feste, perché celebrando le feste si pensava a una felicità possibile anche se remota da tutti e non situata in nessun luogo" (OP II, 621).12 Her family's traditions and their shared belief in a "felicità possibile, a better world or unreachable utopia, had linked past, present, and future.

Thus, her insistence on "il vero" sheds light on the interface in her

12 The loss of future horizons was felt most sharply by women. See "Le donne": "Le donne oggi [...] si accorgono a un tratto che non esiste più il futuro. Esso si è dileguato dal mondo, è fuggito. Non soltanto per loro, ma per tutti. [...] Pensano che loro, le donne, forse erano venute al mondo per amare il futuro, per aspettare, generare, custodire e contemplare il futuro. Era questo che erano venute a fare al mondo e adesso non sanno più cosa devono fare" (OP II, 603). 
writings between her worldview and her poetics, just as her advocating the heteronomy of art mirrors her belief in the responsibilities of the artist to society. While literature "non ha nessun fine se non se stessa" (OP II, 570), 13 its autonomy is not absolute because it does not exist in a vacuum. Rather, the creative work that aspires to the level of "poetry" must impart "un giudizio morale" in a non-hieratic way (OP II, 70, 72). So, given the dialectical interaction of literature and society, one of the primary "duties and responsabilities of poets," and therefore, one of her main criteria for evaluating "poetry," is the work's ability to shatter complacency and shed light on our shared human condition:

[i]l fine della poesia è invece illuminare gli uomini sulle loro malattie e colpe, indicando soccorsi e rimedi e le strade per ottenerli. L'umanità chiede aiuto ed è suo diritto richiederlo ovunque. Avendo i poeti il privilegio dell'invenzione, un simile privilegio devono pagarlo, rendendosi utili. Un simile privilegio non dà loro diritto a libertà o ad altri privilegi, essi non devono essere protetti, ma adoperati. (OP II, 655)

Although Ginzburg had overcome, in the late 1950s and early 1960s, her "fears" of autobiography and her desire to "write like a man," 14 her belief that art should transcend the microcosm, as we have seen, was lasting. ${ }^{15}$ True "poesia" was neither self-reflexive nor egocentric. At the same time, in Ginzburg's parlance, "poetry" did not enjoy the ineffable quality assigned to it by Croce. ${ }^{16}$ For Ginzburg the term "poesia" extended to

13 By this she meant that literature must not serve any agenda, political or otherwise, other than its own ("in verità la poesia non è né utile né inutile, non ha nessun fine chiaro e visibile, e non rassomiglia a nulla" [OP II, 654]), and, furthermore, its content must not be prescribed (OP II, 657).

14 On this topic see Francese, "Natalia Ginzburg: Lessico Famigliare and the Ethics of the Socially Committed Writer."

15 See "Lunico libro di Elizabeth Smart": "Pensiamo di solito che, quando uno scrive, non dovrebbe essere né uomo, né donna, e pensiamo che l'autobiografia dovrebbe essere un fatto incidentale e lasciato alle spalle" (OP II, 524).

16 A fundamenal part of the Crocean esthetics that dominated Italian cultural life from the early part of the twentieth century through at least through the end of World War II was the distinction between meta-historical "poesia" and structural elements within and outside the text, what Croce called "non-poesia." For Croce, history was mere content, raw material for the Spirit, a stimulus for artistic intuition. In Croce's system the Spirit was realized in the "fatto estetico," equivalent in his definition with intuition, a purely intellectual, meta-historical activity that existed independently of the "fatto artistico," the extrinsic expres- 
"ogni forma di narrazione o di espressione fantastica" (OP II, 654) and also denoted the expression of the fundamental experiences that define our humanity, such as death: "[e]vocare i morti senza offesa alla loro memoria e senza offesa a quelli che li hanno amati, è unicamente possibile al linguaggio della poesia." "La poesia" is "honest," that is to say faithful to reality: "veritiera anche quando mescola insieme fatti inventati e fatti reali. La poesia è per sua stessa natura fedele al vero" (OP II, 570). ${ }^{17}$ Because of its allegiance to our most profound emotions and passions, because "[n]asce dal dolore, o dalla collera, o dall'inquietudine, o infine dalla felicità [...] dai desideri inappagati," poetry affords unique and priviledged insight into the human condition. In other words, it cannot be "tepid" (OP II, 573).

For Ginzburg, an emblematic example of "tepidezza" that had overtaken Italians was provided by the Serena Cruz case. To quickly summarize this cause celebre, Serena Cruz was less than two years old when she was adopted by Francesco Giubergia, a railroad worker, and taken from her native Philippines to live with him and his wife, a nurse, in their home near Turin. Fourteen months later, after Giubergia admitted that he had falsified a customs declaration (by claiming he was the girl's biological father) to expedite her departure from her native land, judges ruled the adoption illegal and ordered the child to be re-located in a different home. The case focused attention on the practice, widespread throughout Europe and North America, of taking children from the third world for adoption in the first and on the illegal trafficking, in the developed world, in abandoned babies born in under-developed countries. Defenders of a strict interpretation of Italian law sharply disagreed with those who argued that, since Serena was happy where she was, human considerations should prevail. Ginzburg was unequivocally among the latter. Ultimately, a decision rendered by one of Italy's two supreme tribunals, the Corte di Cassazione, determined that, in

sion, the concrete and therefore historical manifestation of artistic intuition, the "fatto estetico." The "fatto artistico" was merely the practical act infused with artistic intuition; it was an eternalization of the "fatto estetico," which was of primary concern. For Croce the "fatto artistico" would be expended by critical reflection: art was not to be necessarily subjected to contemplation, but was to stimulate the intuitive understanding of the beholder/reader.

17 In "Sul credere e non credere in Dio," which we have already had occasion to cite, she writes: "Dio [...] rassomiglia, mi sembra, alla poesia, nel senso che anche la poesia sempre abita nella concretezza e nella singolarità delle cose e degli esseri, e l'astratto e il generico le ripugna; ma pur abitando ed essendo radicata nella concretezza delle cose e degli esseri singoli, il suo senso e la sua essenza è però universale" (OP II, 171). 
deciding the fate of an adoptive child, juvenile courts must not consider the short-term suffering of parents or that of the child in question but must rule on the future benefits to be derived by the child. ${ }^{18}$

In Serena Cruz o la vera giustizia, Ginzburg argues that the court had dealt with Serena and the Giubergias as if they were abstractions, not as human beings. She also contended that the court would have done much better had it looked beyond the letter of the law, interpreted its spirit, and interacted with real situations and with the persons on whose fate the Court ruled. The Cassazione had utilized a deductive method, whereby a general principle was imposed from on high onto a microreality, when a more flexible, inductive approach (one that was sensitive to the multiplicity of the real) was needed. As a result, a decision that was "giuridicamente ineccepibil[e]" had harmed the lives of the very persons the laws cited in the Court's ruling had been written to protect (Ginzburg Serena Cruz, 25). In point of fact, it might be argued that the Cassazione utilized traditional utilitarian ethics. It engaged in conjecture on future benefits to be derived by the child in the name of a postulated social good; the Court had also intended to set a strong precedent that would discourage illegal trafficking in children. In contrast, Ginzburg maintained that Cassazione's paramount responsibility was protection of the child's rights in the present. It would seem that Ginzburg implicitly argued in favor of a system of moral rights that would have protected Serena Cruz's human right to pursue happiness in a way that did not violate the rights of anyone else. She also seemed to suggest that the Court was motivated more by a desire to punish the Giubergias than by the aspiration to protect the child and her rights.

But more important for our present purposes, Ginzburg's objections to the Cassazione's handling of the Serena Cruz affair transcended the specific legal case. Ginzburg felt that the Court's response was illustrative of a malaise that had become pervasive in Italian society that was, in turn, at the source of her pessimistic outlook that colors her writings and interventions over the last two decades of her life. To explain: the manner in which the court had closed itself up "alteramente nelle proprie argomentazioni verbose, in un altero impasto di false cognizioni psicologiche" was consistent with the "tepid mentality" of the broad majority of a society that had come to eschew "il caldo dell'immedesimazione emotiva" and had begun to take comfort in a "complicità con le istituzioni" and solace in a "rifiuto di opporsi al potere costituito" (Ginzburg Serena Cruz, 39). Furthermore,

18 See Haberman, "Rome Journal," for a concise summary of the case, and also Gordon, "Surviving History." 
the Italian public's indifference to the plight of Serena Cruz was reflective of an equally "tepid," almost Eichmannian banality of thinking and being that had led many to deride the few "comitati di solidarietà" that had sprung up to oppose the Cassazione's decision to place Serena with a new family (Ginzburg Serena Cruz, 85-86). For, Ginzburg these committees were a throwback to better times:

La solidarietà è ormai un sentimento inconsueto. Ovunque regna l'indifferenza per il prossimo e l'impulso a chiudere sulle disgrazie del prossimo la propria porta di casa. È ben raro il calore in questa società attuale che è fatta prevalentemente di tiepidi. (Ginzburg Serena Cruz, 85-86)

In any event, if Mai devi domandarmi is the most metaphysical of Ginzburg's works, then Vita immaginaria is her valediction. In this collection she considers again and personalizes the question of our "broken relationship with the future," closing the essay with an admission that she has reached an age where she is no longer capable of metaphorically conjugating verbs in the future tense:

$\mathrm{Ci}$ accorgiamo $[\ldots]$ che non inventiamo più nel futuro ma nel passato, $\mathrm{e}$ che nell'emendare il passato ci muoviamo in un mondo di cose che riconosciamo e sappiamo impossibili. (OP II, 685)

Or, to phrase it differently, she is no longer confident in her ability to affect change:

Sentiamo una sorta di fedeltà alle cose che sono state, porta il nostro pensiero in un punto opposto a quella che è stata la nostra così lunga vita immaginaria, lo porta in un punto dove tutto è chiaro, inesorabile e reale. (OP II, 685)

In the eponymous essay the author's meditation on her "relationship with fantasy, reality, and writing" (Pflug Natalia Ginzburg, 139) culminates in a re-evaluation of a cornerstone of her poetics, the idea of "otium," or leisure. Leading up to this essay-in "La pigrizia," which deals with her childhood and adolescence- "oziare" is equated with "fantasticare" (OP II, 29), which she had tended to consider a catalyst for creativity. Then, in "Alcuni pensieri sui re" (written in June 1960) she recalls how, as a child, she benefited from the "ozio" that cloistered her "immaginary world" from reality-the "funerario e sanguinario" world of Italy under Fascism (OP II, 588) - but later came to understand that "trovarsi in un luogo bellissimo e avere ozio, solitudine e silenzio" was not the ideal condition for writing: 
in una simile condizione non si scrive più, ci si sente come imbalsamati, e invece si lavora con profitto in posti squallidi, scomodi, nell'ansia, nel disagio, e nel rumore. (OP II, 591).

The trajectory of this reappraisal of leisure is then retraced in "Vita immaginaria." Ginzburg begins with an evocation of her childhood, a time when "ozio" had a positive valence:

Da bambini e da giovani, essere soli e in ozio significava per noi costruire immediatamente luoghi immaginari, e vicende e storie, di cui eravamo i protagonisti. (OP II, 669)

$[\ldots]$

Pensavamo alla vita immaginaria come a una palestra di ginnastica, dove finalmente avremmo imparato una maniera migliore di stare al mondo. (OP II, 672-73)

Ignorance was blissful; childhood was

un tempo in cui avevamo con gli altri rapporti naturali e limpidi. Era un tempo in cui non ci chiedevamo mai se eravamo o saremmo riusciti a essere dei protagonisti. Ci sentivamo fisicamente situati nel centro dell'universo, e meglio ci sentivamo situati nell'unico punto dell'universo che ci sembrava giusto e necessario occupare. (OP II, 684)

It was also a time in which

il silenzio e l'ozio coltivavano idee, non privazioni e non desideri. La nostra vita immaginaria se ne stava in riposo. Rari colloqui immaginari con interlocutori a cui non davamo grande importanza, rari scenari di morte e di gloria, rari squilli di di tromba e suoni di campane e sventolii di bandiere, erano i fiori leggeri e felici che ci portavamo dietro nella felicità. (OP II, 684)

However, over time she learned of the chasm that existed between the two worlds: "[q]uando le mettevamo una davanti all'altra, vita immaginaria e vita reale, le immense differenze fra l'una e l'altra ci davano brividi" (OP II, 673). "Brividi" because in her fantasy world the failure to take an active role in events was condoned:

Nei nostri sogni, spariva in noi la nostra costante paura di non riuscire mai a essere dei protagonisti, e di rimanere per sempre delle comparse. (OP II, 673) 
When, in the decades following the War, protagonism gained in importance, "l'ozio" took on a negative connotation; when this occurred she began to associate "la vita immaginaria" not with leisure but with "la vita morale":

Spesso ci è accaduto di guardare alla nostra vita immaginaria con disprezzo. Abbiamo pensato che essa scorreva lontano dalle scelte dell'intelligenza. Scorreva lontano dalla nostra vita morale. Portava tutti i rifiuti del nostro pensiero. Nei nostri sogni, a volte noi eravamo generosi, caritatevoli, eroici, pronti a ogni sacrificio e martirio. A volte, però eravamo delle carogne. Provavamo, nel comportarci da carogne, una gioia sfrenata. Nella nostra vita immaginaria si raccoglieva dunque la parte peggiore di noi, la parte di noi più crudele, più vana, più millantatoria, più sfaccendata. Il nostro perenne fantasticare, e il tollerarlo, spandeva tolleranza e ozio sulla vita del nostro spirito. (OP II, 676-67)

As a result, she began to look beyond the similarities- "vita immaginaria" and "vita creativa" were both products of fantasy, both "crescevano e maturavano nell'ozio e nella solitudine" (OP II, 677) — and began to distinguish between the two. In this scheme of things the importance of work and of material reality on creative life is vital:

La sola differenza sensibile fra la nostra oziosa vita immaginaria e la vita creativa, era che nella vita creativa il nostro pensiero diventava ronzante e pungente, come se fosse stato pieno di aghi e di api. Nella vita immaginaria, il nostro pensiero era senza aghi e senza api, dolcemente liquido e vuoto. Infine, dalla vita creativa nasceva o potevano nascere opere. La vita immaginaria era sterile, non ne nasceva mai nulla. Ma invero, per noi da giovani questa non era una differenza apprezzabile, perché spesso da ciò che usavamo chiamare lavoro non nasceva nulla ugualmente. (OP II, 677)

To summarize and conclude, in the years following World War II, Ginzburg's youthful belief - that freedom from Fascist despotism would provide a sort of social panacea that would bring in its wake justice and equality-evolved into the belief that only the attainment of justice, grounded in the ideal social equality-could bring freedom for all. In this conception, freedom cannot be realized outside the social constraints. In other words, since freedom is a sort of zero-sum game-the freedom of one cannot be increased without diminishing that of another-it cannot be contemplated outside the constraints of economic justice and of the equality of all before the law. At the center of this perspective is a pluralistic view of politics ("bisogna andare al governo come perdenti" because "si è soli un 
pezzo della vita, e che la vittoria come distruzione dell'altro è inaccettabile" [Ginzburg $\grave{E}$ difficile parlare di sé, 241]) and the understanding that one's own opinion exists only within a field of contention, that "non sei al centro del mondo [...] che gli altri hanno uguale diritto di te" (Ginzburg $\grave{E}$ difficile parlare di sé, 241). The ability to imagine oneself as other and become the other through her art is the font of Ginzburg's creativity. It could not be otherwise, given her insistence on the heteronomy of art, and her belief that "vita creativa" and "vita reale" had to impact each other dialectically. The pessimism of Ginzburg's later years, which finds ample resonance in her creative writing, is due in large part to her belief that Italians had lost the capability and the desire to create such an imaginary world. In addition, the breakdown of the traditional family unit had left the younger generations without points of reference and orientation. She believed that Italians, particularly those of the younger generations, had become egoistical, incapable of imagining themselves as the other, and, therefore, incapable and unwilling to comprehend the fate and the plight of the other. The commitment of many, particularly of her generation, to a long-term, pluralist, egalitarian view of society (see Ginzburg "Arabeschi") had ceded to identity politics on the one hand, and, on the other, a general indifference to the plight of the less fortunate. Over the last two decades of her life she worked to reverse that tide.

\section{MiCHIGAN STATE UNIVERSITY}

WORKS CITED

Baldini, Raffaello. "Questo mondo non mi piace." Panorama (May 3, 1973): 129135.

Bauman, Zygmunt. Does Ethics Have a Chance in a World of Consumers? Cambridge, MA: Harvard University Press, 2008.

Boyers, Peggy. "An Introduction: Natalia Ginzburg in Her Essays." Salmagundi 96 (1992): 54-84.

Blanchot, Maurice. "The Speech of Analysis." In Id., The Infinite Conversation. Minneapolis: University of Minnesota Press, 1993, pp. 230-237.

Dombroski, Robert S. Marxism and Literature in the Postmodern Age. Pullman, WA: Washington State University Department of Comparative American Cultures. Working Papers Series in Cultural Studies, Ethnicity, and Race Relations, 2001.

Francese, Joseph. "Natalia Ginzburg: Lessico Famigliare and the Ethics of the Socially Committed Writer." Journal of Romance Studies: 9-2 (Summer 2009). Ginzburg, Natalia. "I nostri figli." In Natalia Ginzburg: A Voice of the Twentieth Century. Edited by Angela M. Jeannet and Giuliana Sanguineti Katz. Toronto: 
University of Toronto Press, 2000, pp. 226-229.

"Arabeschi." In Lettere da vicino: Per una possibile reinvenzione della sinistra. Edited by Vittorio Foa e Laura Balbo. Turin: Einaudi, 1986, pp. 48-51.

- Opere raccolte e ordinate dall'Autore. 2 volumes. Milan: Arnoldo Mondadori, 1986, 1987.

. Serena Cruz, o la vera giustizia. Turin: Einaudi, 1990.

- E difficile parlare di sé. Edited by Cesare Garboli and Lisa Ginzburg. Turin: Einaudi, 1999.

Gordon, Mary. "Surviving History." New York Times (March 25, 1990): 44-46+. Haberman, Clyde. "Rome Journal; Court Prevents Adoption and Fight Tugs at Child." New York Times (March 1, 1990).

Natalia Ginzburg: A Voice of the Twentieth Century. Edited by Angela M. Jeannet and Giuliana Sanguineti Katz. Toronto: University of Toronto Press, 2000.

Pastore, Judith Laurence. "The Personal is Political: Gender, Generation, and Memory in Natalia Ginzburg's Caro Michele." In Natalia Ginzburg: A Voice of the Twentieth Century. Edited by Angela M. Jeannet and Giuliana Sanguineti Katz. Toronto: University of Toronto Press, 2000, pp. 88-98.

Pflug, Maja. Natalia Ginzburg. Arditamente timida: una biografia. Trans. Barbara Griffini. Milan: La Tartaruga, 1997.

Woolf, Judith. "Silent Witness: Memory and Omission in Natalia Ginzburg's Family Sayings." Cambridge Quarterly 25:3 (1996): 243-262. 